\title{
A GLYCOSIDE OF MYRICETIN FROM THE FLOWERS
}

OF Hibiscus cannabinus

Z. P. Pakudina and B. Maksudova

UDC 547.972

Flowers of Hibiscus cannabinus (kenaf), family Malvaceae, of variety 1574, were collected in August 1974 in the Kirov kolkhoz (collective farm), Nizhnechirchikskii Region, Tashkent oblast. A quantitative determination showed the presence in it of more than $4 \%$ of combined flavonoids, including five substances with $R_{f} 0.18$, $0.27,0.55$, and 0.66 (BAW) [sic].

After preliminary pre-extraction of the flowers with chloroform, the flavonoids were extracted by heating with $70 \%$ methanol three times. The methanol was distilled off, and the flavonoids were extracted from the aqueous residue with ethyl acetate. After 3-4 days, the concentrated ethyl acetate extract deposited lemonyellow crystals of substance (I) (yield $1 \%$ on the weight of the flowers).

Substance (I), dried at $105^{\circ} \mathrm{C}$, had $\mathrm{mp} 198-200^{\circ} \mathrm{C}$, and when dried at $120^{\circ} \mathrm{C}$ its mp was $238-240^{\circ} \mathrm{C}$ and its composition $\mathrm{C}_{21} \mathrm{H}_{20} \mathrm{O}_{13} ; \mathrm{R}_{f}$ on paper 0.18 (BAW), 0.27 (60\% acetic acid), and on Silufol plates 0.72 (BAW); $[\alpha]_{\mathrm{D}}^{23}+1.93^{\circ}$ (c 0.1 ; dimethylformamide). UV spectrum: $\lambda \max 374,254 \mathrm{~nm}\left(\mathrm{C}_{2} \mathrm{H}_{5} \mathrm{OH}\right) ; 376,252 \mathrm{~nm}\left(\mathrm{C}_{2} \mathrm{H}_{5} \mathrm{OH}\right.$ $\left.+\mathrm{CH}_{3} \mathrm{COONa}\right) ; 388,258 \mathrm{~nm}\left(\mathrm{C}_{2} \mathrm{H}_{5} \mathrm{OH}+\mathrm{CH}_{3} \mathrm{COONa}+\mathrm{H}_{3} \mathrm{BO}_{3}\right) ; 438,268 \mathrm{~nm}\left(\mathrm{AlCl}_{3}\right)$; acetyl derivative, $\mathrm{C}_{39} \mathrm{H}_{38} \mathrm{O}_{22}$, $\mathrm{mp} 210^{\circ}$; methyl ether, $\mathrm{mp} 149-150^{\circ} \mathrm{C}$.

The hydrolysis of (I) by heating it with concentrated hydrochloric acid for 15 min or with $10 \%$ HCl for $4 \mathrm{~h}$ led to glucose $\left[R_{f} 0.59\right.$, ethyl acetate-pyridine-water $\left.(2: 1: 2)\right]$ and an aglycone, (II), with the composition $\mathrm{C}_{15} \mathrm{H}_{10} \mathrm{O}_{8}$, mp $340^{\circ} \mathrm{C}$; mol. wt. 318 (mass spectrometry). UV spectrum: $\lambda_{\max } 372,253 \mathrm{~nm}\left(\mathrm{C}_{2} \mathrm{H}_{5} \mathrm{OH}\right) ;$ acetyl derivative, $\mathrm{mp} 220^{\circ} \mathrm{C}$; pentamethyl ether, $\mathrm{mp} 194-196^{\circ} \mathrm{C}$. $1: 1$.

The physicochemical constants of (II) coincide with those of myricetin. The ratio of (II) and glucose was

The PMR spectra of the acetyl derivatives of (I) - (III) - and of (II) - (IV) - showed the following features: in (IV) in the weak-field region there were three signals. Two doublets at 7.34 and $6.86 \mathrm{ppm}(\mathrm{J}=2 \mathrm{~Hz}) \mathrm{relate}$ to the H- 8 and H-6 protons, respectively. A singlet at $7.60 \mathrm{ppm}$ with an integral intensity corresponding to two protons relates to the equivalent $\mathrm{H}-2^{\prime}$ and $\mathrm{H}-6^{\prime}$ protons of ring $\mathrm{B}$. Six signals in the 2.2-2.9-region show the presence of $\mathrm{O}-$ acetyl groups at $\mathrm{C}-3,3^{\prime}, 4^{\prime}, 5,5^{\prime}$, and 7 . In the spectrum of (III), the number of aromatic Oacetyl groups in the 2.2-2.4-ppm region has decreased to 5, the chemical shifts of the H-6 and $H-8$ protons have remained unchanged, and the signals of the $\mathrm{H}-2^{\prime}$ and $\mathrm{H}-6^{\prime}$ protons have shifted upfield (7.3 ppm) in comparison with the spectrum of (IV) by $\Delta=0.23 \mathrm{ppm}$. Consequently, the glucose is attached to (II) in the C- $3^{\prime}$ or C- $5^{\prime}$ position.

Analysis of the IR spectra and differential IR spectra (the presence of bands at 1079 and $1037 \mathrm{~cm}^{-1}$ ) of (I), and also a molecular rotation calculation according to Klyne [1] showed the presence of D-glucose in the furanose form attached in the equatorial position.

For compound (I) we propose as the most probable structure myricetin $3^{\prime}$ - (or 5'-)- $\alpha$-D-glucopyranoside. In its physicochemical properties, substance (I) differs from the cannabiscitrin isolated by Seshadri et al., [2, 3] from Indian varieties of kenaf.

\section{LITER A T URE CITED}

1. W. Klyne, Biochem. J., 47, No. 4, xli (1950).

2. T. $R$. Sheshadri and U. Vencateswarly, Proc. Indian Acad. Sci. 23A, 296 (1946).

.3. R. S. Rao and T. R. Sheshadri, Proc. Indian Acad. Sci., 14A, $26 \overline{(19} 41)$.

V. I. Lenin Tashkent State University. Translated from Khimiya Prirodnykh Soedinenii, No. 3, pp. 388389, May-June, 1976. Original article submitted December 14, 1975.

This material is protected by copyright registered in the name of Plenum Publishing Corporation, 227 West 17th Street, New York, N.Y. 10011. No part of this publication may be reproduced, stored in a retrieval system, or transmitted, in any form or by any means, electronic, mechanical, photocopying, microftiming, recording or otherwise, without written permission of the publisher. A copy of this article is available from the publisher for $\$ 7.50$. 